\title{
Cuerpo y espacio, estudio de la escena poética del texto Altazor de Vicente Huidobro y del montaje Un viaje en parasubidas $^{1}$
}

\section{Body and Space, a Study of the Poetic Scene of Altazor by Vicente Huidobro and the staging of Un viaje en parasubidas}

\author{
Pía Salvatori Maldonado \\ Università degli Studi di Firenze, Italia / Becaria CONICYT \\ pia@salvatori.cl
}

Resumen - Altazor o el viaje en paracaídas es valorado como un texto dramático, donde se reconoce una acción y un sujeto que la realiza. El poema tiende naturalmente a la presentación visual de las situaciones descritas que localizo especialmente en el entramado lingüístico y en las figuraciones del cuerpo del personaje. En base a estas características, se concibe la puesta en escena de Un viaje en parasubidas que exalta lo visual en el poema, el cuerpo y el gesto del actor, para presentar una de las tantas lecturas elaboradas en tono al poema de Huidobro. Este trabajo se propone el estudio paralelo de la escena poética y la escena teatral desde un objeto común: el cuerpo de un sujeto en escena.

Palabras clave: Altazor, Escena, Cuerpo, Figura, Performance

Abstract - Altazor o el viaje en paracaídas is valued as a dramatic text, where an action is recognized and a subject realized. The poem naturally tends to the visual presentation of the situations described, situated especially in the linguistic framework and in the figurative body of the character. The stage is conceived under these characteristics, Un viaje en parasubidas extols the visuals of the poem, the body and the gesture of the actor so as to present one of the many reading tones in elaborated in Huidobro's poem. This paper proposes a parallel study of the poetic and theatrical scene from a common object, the body of a subject in scene.

Keywords: Altazor, Scene, Body, Figure, Performance

\footnotetext{
Este trabajo es la síntesis de una investigación más detallada realizada durante el 2010.
} 
Este trabajo tiene como objetivo describir el proceso de significación de dos objetos artísticos diversos, el texto poético Altazor y una puesta en escena del mismo², a través de un referente común, el cuerpo de un sujeto en escena. Altazor o el viaje en paracaídas de Vicente Huidobro es un poema estructurado como una narración, donde es posible reconocer un personaje emplazado en un espacio y tiempo determinados. Desde esta característica, se plantea la puesta en escena Un viaje en parasubidas que propone una lectura del texto situando especialmente la narración de la acción en el cuerpo del actor y su lenguaje físico ${ }^{3}$.

Propongo retomar el concepto de escena para el estudio de ambos sistemas semióticos, ya que como señala M. Contreras: «las unidades escénicas, sin ser unidades rígidas, permiten entrar en el texto reconociendo los intercambios comunicativos (de toda índole) que aglutinan los sentidos diversos del texto instalados tridimensionalmente en la escritura» (Contreras, Escenas casi familiares, 150). El reconocimiento y el análisis de las escenas permitirán hacer énfasis en el sujeto: describiendo su ubicación, traslados, transformaciones y figuraciones asumidas a lo largo de una acción ${ }^{4}$. La exploración de las escenas en ambos objetos artísticos permitirá describir una retórica del cuerpo del personaje, suprimiendo las complicaciones obvias que supone el estudio de sistemas semióticos diversos. En este contexto, se enfatiza en el análisis del cuerpo como referente principal del enunciado/enunciación de un discurso y como instrumento que performativiza las figuras desarrolladas en la escena, para descubrir los entramados de relaciones y sentidos que están operando culturalmente.

\section{LA ESCENA POÉTICA EN ALTAZOR O EL VIAJE EN PARACAÍDAS: APROXIMACIONES CRÍTICAS AL TEXTO}

El poema Altazor es la matriz textual de la puesta en escena que a su vez escoge y representa, en la materialidad del escenario y del actor, un sentido entre los muchos evocados. Vicente Huidobro escribe el poema Altazor o el viaje en paracaídas durante 1919 y 1931;

2 Se entiende el concepto de puesta en escena como un sistema semiótico diferente al del texto, pero percibidos en un mismo tiempo y lugar. «La puesta en escena es una hipótesis sobre una enunciación que llega a la concretización de enunciados sin cesar nuevos y en continua transformación [...] no es pues solamente una concretización-ficcionalización como toda lectura de un texto escrito, es una búsqueda de enunciadores escénicos que, reunidos por la puesta en escena, produce un texto espectacular global, dentro del cual adquiere un sentido muy específico" (Pavis, Diccionario de teatro, 95).

3 La perspectiva de este estudio es doble, por una parte se trata del estudio teórico-literario de un texto, y por otra, la visión aportada desde mi participación activa y creativa como intérprete del montaje. La riqueza de esta perspectiva presenta una lectura crítica y contextualizada del poema, inserta en un periodo histórico y social determinado, sin excluir ambas visiones. Cabe señalar también que este estudio está impregnado de la identidad de una puesta en escena, construida en una visión colectiva, donde sujetos determinados le han dado un sentido específico.

4 Retomo el concepto de figura desde la reflexión de Contreras en Griselda Gambaro. Teatro de la descomposición. La investigadora analiza la escritura dramática de Gambaro a través del estudio del cuerpo que en su materialización literario-teatral propone llamar figura: «la figura es la escenificación de una serie de gestos verbales y corporales específicos cuya exposición abre zonas críticas, cargadas, no resueltas de la vida contemporánea. El presentar una historia se resuelve en una composición que incluye la gestualidad corporal más otros procedimientos dialógicos en la serie de los performativos y anafóricos siguiendo una tradición literaria contemporánea que valoriza el carácter material de los cuerpos y de los objetos» (Contreras, Griselda Gamabaro, 10). 
durante ese período partes del texto fueron publicadas en francés y español. Compuesto por un prefacio y siete cantos, la construcción del poema implica la trasgresión a nivel semántico, sintáctico y morfológico de la lengua. El texto fue escrito en el contexto de las vanguardias de inicios del siglo $\mathrm{xx}$; movimiento surgido como interrupción y ruptura con la tradición impuesta por el racionalismo moderno, donde el imperio de la razón crítica tendía a una constante negación de principios, costumbres, ideas, estilos, creencias, etc. La actitud vanguardista evidenció esta pérdida de los valores culturales de una tradición unificadora, a través de la crítica irónica y la angustia existencial, la exacerbación en la percepción fragmentaria de la realidad y la conciencia del instante. El artista entonces, es el 〈sacerdote〉 mediador que busca y restituye a través de su arte la religiosidad perdida: «el poeta dice y, al decir, hace» (Paz, 93). El poema es un espacio de autocreación, una unidad que funciona como una versión de otras realidades. Esta búsqueda de nuevas referencias, la idea de traducción y de ruptura, la reformulación constante de la realidad, son aspectos comunes a los movimientos de vanguardia. Las vanguardias, más que un hecho artístico, tienen un trasfondo ideológico como respuesta a un hecho histórico y mundial.

El creacionismo en Chile (1912) aparece al mismo tiempo que el ultraísmo, el cubismo, el futurismo y el surrealismo ${ }^{5}$. Uno de los principios claves en la poética huidobriana es la supremacía de la imagen, es decir, el poema es un objeto que no pretende describir sino presentar ${ }^{6}$. A través de las imágenes suscitadas en el poema, el poeta descubre las relaciones escondidas entre los objetos: «la imagen constituye una revelación [...] para el poeta creacionista será una serie de revelaciones dadas mediante imágenes puras, sin excluir las demás revelaciones de conceptos ni el elemento misterio, la que creará aquella atmósfera de maravilla que llamamos poema» (Huidobro, Obras selectas, 259). Las imágenes creadas deberán ser inhabituales, sorprendentes y convincentes, sugeridas a partir de objetos que manejamos con frecuencia; en dicho proceso creativo, el poeta desordena las categorías del lenguaje proponiendo otros sistemas simbólicos para nombrarlo y así ilustrar los hechos insólitos aludidos en el poema ${ }^{7}$ En Altazor o el viaje en paracaídas, el instrumento de creación de otros mundos es por excelencia la metáfora: «La metáfora es el resultado de un proceso de interacción entre dos términos por el cual uno de ellos siempre textualizado, pierde su propia referencia, la sustituye por la del otro, expreso o latente, y organiza su estructura semántica con rasgos de significados de ambos» (Bobes

$5 \quad$ En Chile, Huidobro pertenece al primer grupo de vanguardia surgido durante el primer cuarto del siglo XX, donde también destacan: De Rokha, Guzmán, Cruchaga, Mistral, entre otros (periodización propuesta por Muñoz y Oelker).

6 La primacía de la imagen y la técnica son preocupaciones recurrentes en otras corrientes de vanguardias simultáneas al creacionismo. Movimientos como el futurismo y el cubismo aportan diversas perspectivas que pueden ser comparadas con algunos postulados en la poética creacionista. En relación a la conexión entre creacionismo y cubismo, el poema se debe entender como una unidad, un dominio cerrado donde el mundo fluye y confluye en él, instaurando sus propias leyes de realidad; al igual que un cuadro cubista, el poema se erige como una unidad visual determinada por: la página (el soporte de papel), la puntuación, el uso de los espacios en blanco, las letras mayúsculas y la superposición de las perspectivas como en un montaje cinematográfico. Desde el futurismo se plantea la supremacía del instante, por consiguiente todo en el poema será presente, cambio continuo, velocidad y dinamismo. Se valora el registro de lo concreto y la materia como soporte de lo acontecido en el poema. Más adelante, se desarrollarán algunas de estas ideas a través de ejemplos concretos presentes en el poema.

$7 \quad$ En Creación pura, el poeta expone su método poiético que consiste en seleccionar del mundo objetivo diversos elementos de la naturaleza (lo que llama sistema), los que pasan a su mundo subjetivo y luego, mediante una técnica específica, los presenta como hechos nuevos al mundo objetivo. 
Naves, 117). Este enfoque define el concepto como interacción - y no sólo sustitución-, intensificando y ampliando el significado de los términos. A través de la metáfora, el discurso poético de Huidobro lleva al extremo la arbitrariedad del signo lingüístico, buscando establecer nuevas relaciones entre los elementos nombrados.

En el proceso de interacción metafórica quedan involucrados: el plano de valores lingüísticos (semánticos, fónicos, morfológicos y pragmáticos) y el plano referencial extralingüístico a los que aluden los objetos de ambos términos (cosas, ideas, conceptos, sentimientos, entre otras). Dicha interacción, establece una implicancia entre los planos mencionados fundada en las características compatibles de los referentes; de allí que «la metáfora es un proceso de selección sémica y de organización jerárquica entre los semas compatibles de los dos términos» (Bobes Naves, 106); en otras palabras, son las implicancias o los supuestos los que permiten establecer dichas conexiones. A través del proceso poiético llevado a cabo por la metáfora, el autor propone nuevos sentidos creando imágenes nuevas, resistentes y separadas de la realidad dada- que a su vez el lector interpretará. El mundo narrado en el poema presenta un sistema autopoiético, es decir, que se reproduce constantemente a sí mismo y donde la nueva imagen es el contenido y la frontera de éste ${ }^{8}$. Guillermo Sucre advierte cómo la construcción de este mundo paralelo en Altazor o el viaje en paracaídas implica un sistema de relaciones propiciado por la vuelta a las palabras más que al mensaje; el texto propone una ‘trama visual (una atmósfera, un espacio y sus objetos, vale decir, una imagen) más que expresar un estado de ánimo. Éste es uno de los aspectos fundamentales del texto - y de la poética creacionista-, el predominio de la imagen, es decir, su materialidad tanto a nivel de escritura como a nivel metalingüístico.

Esta 'presentación visual del acontecer en el poema tiene que ver con el concepto de exteriorización. En Creación pura explica: «no se trata de imitar la naturaleza, sino de proceder como ella, no imitar sus exteriorizaciones, sino su poder exteriorizador» (Obras selectas, 248). La exteriorización significa hacer patente), 〈develar〉 o 〈mostrar〉 y es a través de la poesía que el poeta exterioriza las cosas. El poeta apela a esa exteriorización en variadas maneras: a través de la disposición especial de párrafos y versos, el ritmo musical de los mismos, la transferencia de atributos sensibles a un objeto abstracto, la proyección visual o corporal de estados emocionales y espirituales, entre otras estrategias de mostración. Hablar de exteriorización es aludir a la capacidad performática del lenguaje, de allí que Huidobro conciba su poesía como acto, como una ‘presencia〉 que es percibida y reconocida a través de la imagen evocada. Así, cada vez que el lector se enfrenta al poema y le da sentido, reactualiza las construcciones metafóricas creadas por el autor.

Si la poética creacionista concibe el poema como acto y pone énfasis en los acontecimientos sugeridos por él, será posible entonces reconocer en él una acción. Aristóteles en su Poética define acción como una unidad completa, es decir, un relato dotado de inicio, medio y fin, con los hechos ordenados artísticamente de estructura lógico-causal (donde se corresponda la sucesión de un hecho con otro). En Altazor es posible reconocer una

\footnotetext{
Marta Rodríguez reflexiona sobre el fenómeno de la autopoiesis en los textos de Huidobro, poniendo especial énfasis en el proceso del delirio poético vivido por el autor y la metáfora como instrumento creador. Todo sistema autopoiético se puede describir como «un dominio cerrado de operaciones delimitado por un límite [...] implicando procesos de autogénesis y autorregulación por efectos recíprocos entre los elementos autoconstituidos (73).
} 
acción central realizada por un personaje y emplazada en un espacio y tiempo determinados. Aristóteles explica la correspondencia entre acción y héroe desde el carácter de este último, en los elementos de ethos y pathos se comprende la realización de tal o cual acción, es decir, el carácter se revela en la realización de una acción: «se revisten los caracteres a causa de las acciones» $(1450 a)$. El cumplimiento de una acción conlleva la transformación del personaje.

La fábula contada en el poema se puede resumir como el relato arquetípico del viaje. Un arquetipo designa contenidos de carácter arcaico y de naturaleza universal. Estos contenidos son posibilidades designadas a priori de la forma de representación, de allí que se pueda reconocer un 'núcleo. Esto hace que un relato arquetípico sea repetido y actualizado una y otra vez, para volverse una historia fundacional.

El significado simbólico del viaje se puede resumir en algunos aspectos: búsqueda de la verdad, de la paz, de la inmortalidad y el descubrimiento espiritual. Dicha búsqueda refiere también: conocimientos, pruebas preparatorias a una iniciación, el camino al interior del ser o a una huida. El viaje implica una aventura y una peregrinación. Chevalier y Cheebrant señalan: «el viaje expresa un profundo deseo de cambio interior, una necesidad de experiencias nuevas, más que un desplazamiento local. Según Jung, es testimonio de una insatisfacción, que impele a la búsqueda y al descubrimiento de nuevos horizontes» (1067). En estudios precedentes sobre el poema, la escena global trata de la búsqueda de sí mismo, la búsqueda como un viaje desde fuera hacia zonas cada vez más internas de la personalidad que serán también las más desconocidas.

El mundo de Altazor es la aventura, una aventura que se sustenta en la búsqueda de un fundamento de la existencia, la rebeldía y la negación ${ }^{9}$. Sucre hace énfasis en una particularidad de esta conciencia fatal y la angustiosa, ya que no le impiden abandonar el entusiasmo que suscita el acto purificador de la creación poética, poniendo en ella la esperanza de nuevos aconteceres. Pese a estas contradicciones, Altazor está continuamente en una posición de dominio del destino irrevocable al que se somete y sus tránsitos son siempre conscientes; el humor negro y la ironía impregnan sus visiones y lo instalan fuera de ella. La evidencia de la paradoja y del absurdo, que reconoce en su realidad, le provocan un sinnúmero de emociones y visiones extremas. La exasperación, el extravío, la alucinación y el extremismo son sensaciones que el poeta privilegia en la escritura del poema.

Estos aspectos son ejes en la constitución del carácter del personaje y serán develados en la sucesión de las acciones y su materialización en cuerpo del protagonista. El cuerpo es el lugar desde donde se narra la historia y se construyen los sentidos sugeridos en el poema, existiendo en la medida en que figura o representa los significados, y los significados existen en la medida en que interfieren, se conectan o pasan por el personaje, quedando abolidas las dicotomías mente/cuerpo, logos/sentidos sensoriales.

\footnotetext{
9 Fernando Savater reconoce tres rasgos que anuncian y/o acompañan el motivo de la aventura del héroe: la aventura como tiempo lleno frente al vacío de lo cotidiano, como un tiempo inseguro e imprevisible y la presencia constante de la muerte. En esta búsqueda subyace la realización plena de su carácter y su fin: «el aventurero no se juega la vida, pues ésta es simplemente lo que pretende ganar de modo reafirmado y merecido: se juega la muerte, el lote inevitable de la cotidianidad anestesiada, la permanente coartada de lo que propone su mediocridad sin peligro y abomina del arriesgado esplendor» (172). Como veremos, Altazor comparte y evidencia esta crisis, todos sus gestos y sus acciones se ordenan en el espíritu renovador que le mueve.
} 
La exteriorización de los contenidos permite describir una retórica que se apoya también en la arquitectura visual del texto, en donde se evoca visualmente lo transmitido a nivel metalingüístico (ejemplos que serán entregados más delante). Altazor es una figura hecha de lenguaje y el poema se encarga de presentar sus transformaciones y cambios, propiciando la unidad entre el héroe y lenguaje. El acto performático es realizado en el cuerpo del personaje; dicha capacidad transformadora hace también referencia a la unidad entre el lenguaje y Altazor, es una puesta en evidencia y una concreción de los sentidos sugeridos en el poema.

\section{DE LA ESCENA POÉTICA A LA ESCENA TEATRAL EN UN VIAJE EN PARASUBIDAS ${ }^{10}$}

Esbozadas las características del texto, veremos cómo se escenifican en Un viaje en parasubidas, montaje de danza-teatro, basado en el poema de Huidobro y dirigido por Leonardo Iturra. La puesta en escena trabaja con un corpus de signos polifónicos, vale decir que un mismo signo remite variados significados dependiendo de la escena en que sean interpretados, y polifuncionales, especialmente los que competen a la escenografía y el vestuario ${ }^{11}$. Para facilitar el análisis, la obra fue dividida en escenas que coinciden con la división de los cantos en el texto poético original, y en cada parte la descripción estará centrada en los signos emitidos por el actor ${ }^{12}$.

\section{1.- PREFACIO: LA EVOCACIÓN Y LA PARTIDA}

El Prefacio se desarrolla como un texto escrito en prosa, aspecto que de alguna manera exterioriza el carácter narrativo del poema. Configurado como un racconto realizado en el presente, sitúa al lector/espectador y enmarca el relato del viaje del protagonista; durante el discurso se registran repentinos saltos en los tiempos verbales que tienen que ver con la proyección de los recuerdos y los deseos del futuro en un tiempo presente. En la puesta en escena, son cinco los actores que representan al único personaje (ver imagen 1). Esta estrategia dramatúrgica pretende resaltar la complejidad del carácter del protagonista, haciendo énfasis en la multiplicidad y contradicción de su personalidad:

10 Montaje realizado en Concepción durante el 2008 y el primer semestre del 2009 por la compañía $L a$ Calandria, actúan: Fredy Flores, Royer Leal, Roberto Roa, Mishka Soto y Pía Salvatori.

11 F. de Toro explica la polifuncionalidad del objeto como el signo que además de ser signo de uno que él mismo representa, puede también adquirir funciones de otros sistemas. Durante el análisis veremos cómo esta cualidad del signo está siempre presente.

12 Estos son: el texto enunciado (la palabra y el tono), la expresión corporal (la mímica, el gesto y el movimiento — cinética y proxémica-) y el vestuario. 


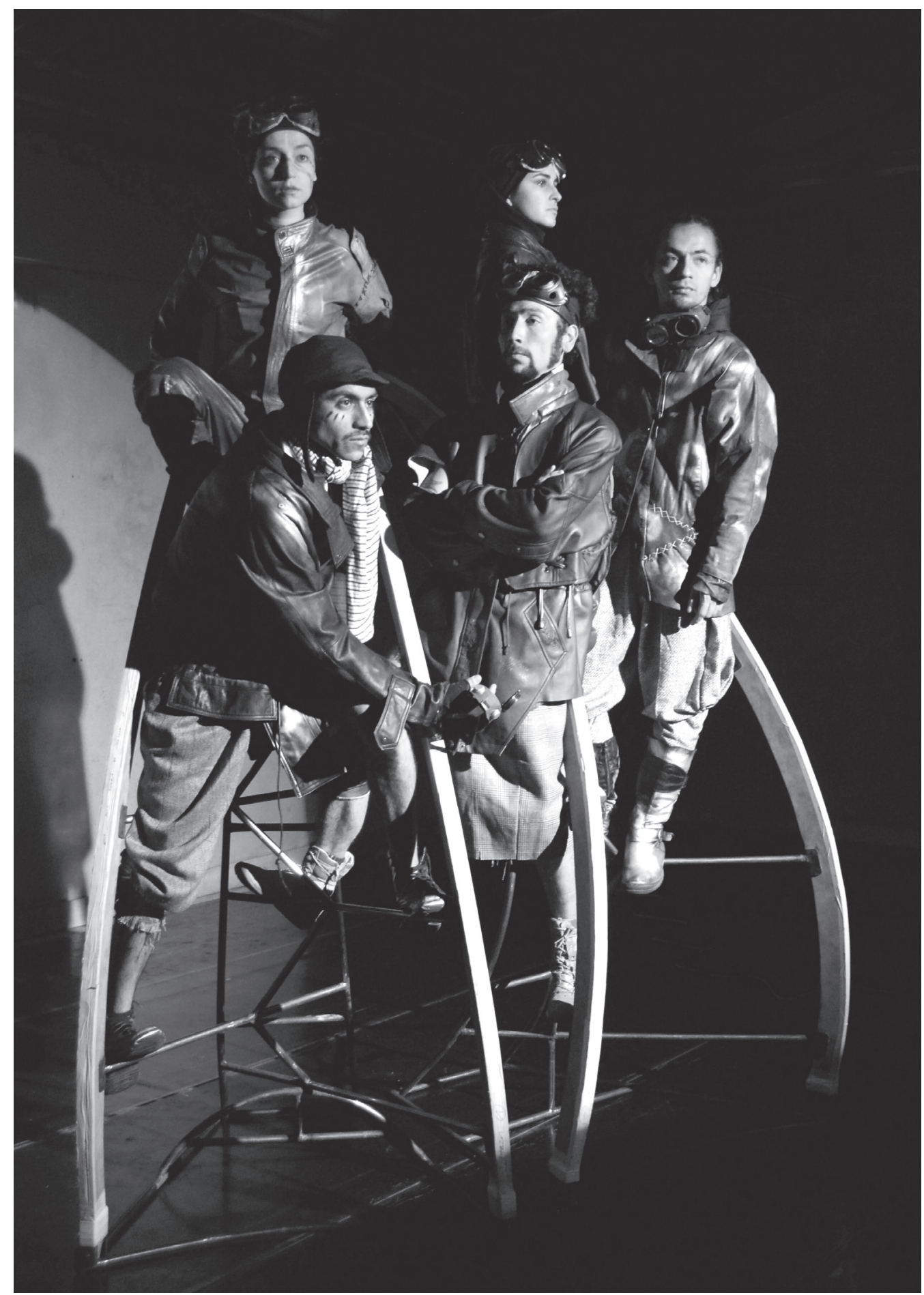

1. Fotografía de Claudio Quiroz para Un viaje en parasubidas, 2008. 
Todos: nací a los treinta y tres años / el día de la muerte de Cristo / nací en el equinoccio / bajo las hortensias y los aeroplanos del calor / tenía yo un profundo mirar de pichón, de túnel, de automóvil sentimental [...] Y ahora mi paracaídas cae de sueño en sueño por los espacios de la muerte (Huidobro, Obras completas, 365) ${ }^{13}$.

Altazor evoca su pasado, tiempo lejano de ingenuidad y nostalgia; el discurso polifónico de los actores es enunciado en primera persona. En el espacio escénico, los actores se ubican en altura sobre las estructuras en un ángulo del escenario. Enuncian el texto sin movimiento alguno, lo que facilita la focalización en el texto. El tono de la declamación es tranquilo y nostálgico.

Altazor deja la cima de su nave y sus recuerdos, se sitúa en el tiempo presente y comienza la experiencia del viaje en el espacio sideral abierto. Los actores exploran el espacio (ver imagen 2), las indicaciones del director referentes a las coordenadas espacio temporales de la escena - y de la obra en general-, apuntan a la evocación de un lugar etéreo: la cualidad del movimiento es liviana y periférica, siempre en la tensión que supone la exploración de un sitio desconocido y ocupando los tres niveles de movimiento (bajo, medio y alto). La travesía presentada por cada actor se vuelve una aventura personal, ya que cada uno construye una narración desde sus movimientos: aceleración/lentitud, encuentros maravillosos, colisiones, emergencias, entre otras acciones. La intención emocional de esta estación varía entre: sorpresa, vértigo, confusión, pérdida de la gravedad, liviandad, equilibrio precario, etc., de cualquier forma, la indicación principal del director, es que se trata de mostrar esta aventura agradable para el personaje. Todas las características del espacio y las acciones del protagonista se exteriorizan a través de la kinética corporal de los actores, de cualidades: leve, lenta o abrupta y recurrentemente periférica ${ }^{14}$.

El Prefacio cierra con la imagen de un descenso abrupto y veloz que es retomado en el canto siguiente.

\section{CANTO I: LA CAÍDA}

Se abre la escena con el sujeto sumido en sus pensamientos; éste percibe la soledad que le rodea. Instalado en las alturas y habitante de los cielos - lugar donde por antonomasia residen las divinidades-, goza de un poder ligado a la conciencia lúcida y dolorosa. En la puesta en escena, un actor está de pie sobre las estructuras, monologa consigo mismo, su voz es la síntesis de las subjetividades de Altazor.

Altazor 2: Altazor, ¿Por qué perdiste tu primera serenidad? ¿Qué ángel malo se posó en la puerta de tu sonrisa con la espada en la mano? ¿Quién sembró la angustia en tus ojos como el adorno de un dios? ¿Por qué, un día de repente, sentiste terror de ser? Y esa voz que te gritó vives y no te ves vivir, ¿Quién hizo converger tus pensamientos en el cruce de todos los vientos del dolor?

13 Todas las citas del poema desde aquí en adelante harán referencia al texto adaptado para la puesta en escena pero para efectos de la escritura del artículo me remitiré a la fuente del texto original con que se trabajó para dicha adaptación. Ver referencias bibliográficas.

14 Terminología propuesta por Laban desde el estudio de la eukinética. En función de los objetivos de este estudio, algunas cualidades del movimiento son: según el factor tiempo (lento o rápido), factor espacio (periférico - movimiento desplegado al exterior-, central — tiende hacia el centro del cuerpo-) y el factor energía (débil y fuerte). 


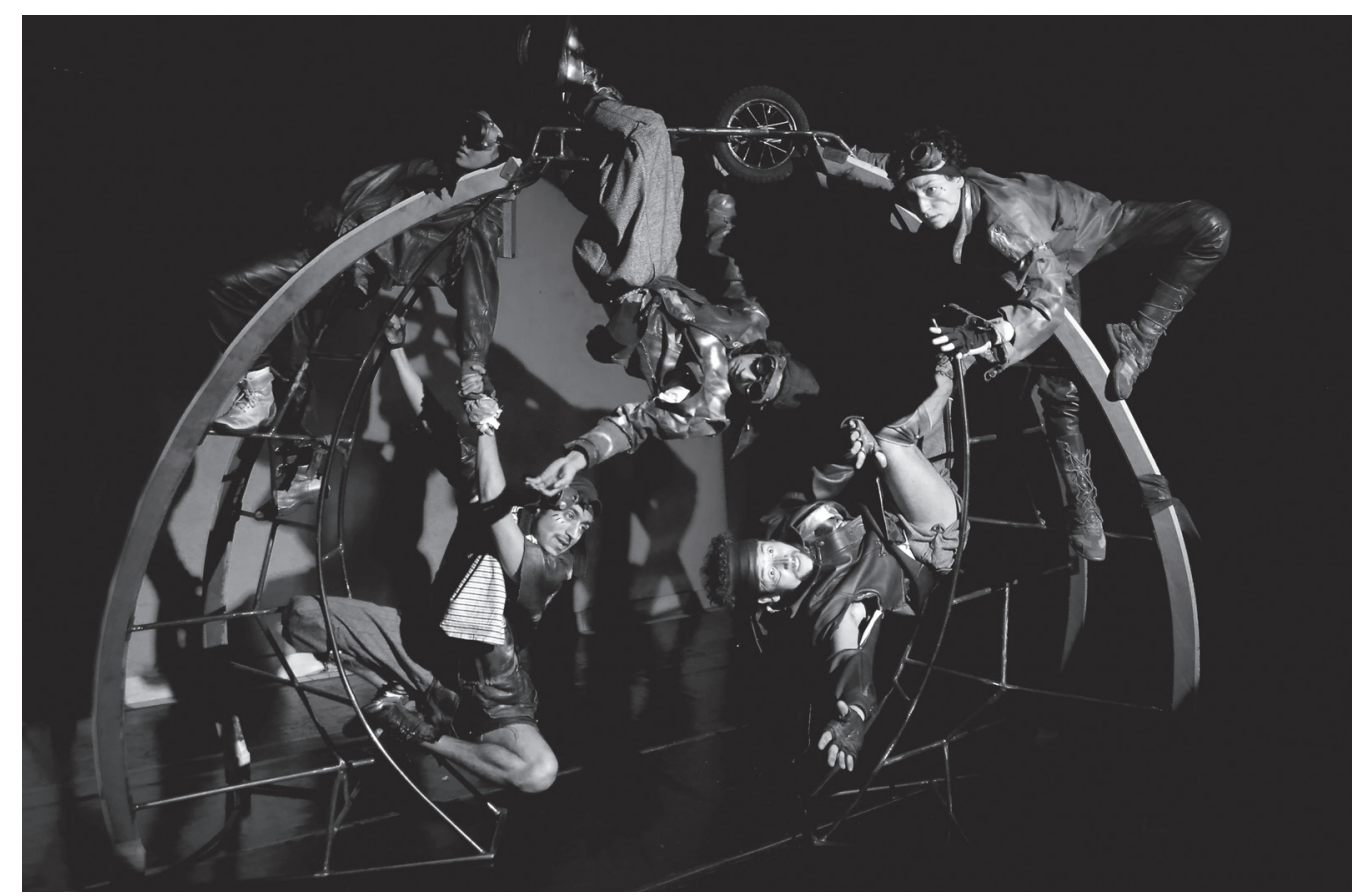

2.- Fotografía de Claudio Quiroz para Un viaje en parasubidas, 2008.

Altazor 1: Estás perdido Altazor, solo en medio del universo, solo como una nota que florece en las alturas del universo [...]

Todos: ¿En dónde estás Altazor?

Altazor 4: ¿No ves que vas cayendo ya? (Huidobro, Obras completas, 368)

El discurso apela al estado de la autoconciencia, la autopercepción y la crítica. El sujeto evidencia las contradicciones entre lo que ve y siente. Esta perspectiva queda en evidencia a través del dialogismo que domina la mayor parte del poema, la mirada desdoblada tiende a traspasar las fronteras del yo para penetrar en los espacios insondables de la realidad dada; el espacio da lugar a preguntas retóricas e interlocutores mudos.

El estado interno de angustia le obliga a descender no sólo físicamente sino que también a sí mismo, la caída es un acto de despojo y derrumbe de todo paradigma, un acto físico y espiritual ${ }^{15}$. En la puesta en escena, este momento es presentado por los actores que se precipitan en caída libre hacia atrás, desapareciendo en la oscuridad del escenario. Al igual que en el poema donde la palabra caer es una anáfora, en la escena teatral esta acción es repetida. Una voz en off acompaña el momento: «cae, cae eternamente, cae en infancia, cae en vejez, cae en música sobre el universo, cae de tu cabeza a tus pies, cae de tus pies a tu cabeza [...]» (Huidobro, Obras completas, 368).

15 Algunos críticos como Schopf interpretan este acontecimiento como el suceso que conduce el poema, visto así, el poema presenta el proceso de declinación y desintegración del sujeto. La caída, como alegoría del curso natural de la vida, es retardada por efecto del paracaídas, retrasando también la fatalidad del aniquilamiento. 
La acción de caer supone la renuncia, el despojo o el ocaso de las cosas que Altazor debe abandonar. El carácter liberador de la caída, la constituye en una ‘acción recurrente> en las escenas que siguen, ya que no sólo el personaje se precipita al vacío, las imágenes y los objetos se precipitan sobre él. Estos aspectos están exteriorizados en la configuración visual del texto, compuesto de estrofas de diversa extensión carentes de signos de puntuación y en estrecha relación semántica. En la puesta en escena, estos aspectos se concretizan en las imágenes que se suceden frenéticas una a otras; la kinética de los cuerpos durante esta estación es principalmente rápida, fuerte y periférica. En el ámbito de estas cualidades, los actores buscan comunicar con distintas partes del cuerpo: caderas, codos, rodillas, pies, ombligo, entre otras. Los movimientos resultan grotescos y absurdos generando un contrapunto irónico e incoherente de frente a la dramaticidad del texto, reflejando la crisis intensa en que se encuentra el personaje. Los actores se mueven entre movimientos y textos en dicha contradicción y la fuerza y la angustia extrema de la locura que posee al personaje:

Altazor 2 (burlesco): ¿Eres tú el ángel caído? La caída eterna sobre la muerte, la caída sin fin de muerte en muerte.

Altazor 1: Soy el ángel salvaje que cayó un mañana en vuestras plantaciones de preceptos, culto, anticulto, solitario como una paradoja, paradoja, flor, de contradicciones, bailando un fox trot sobre el sepulcro de Dios, soy un pecho que grita y un cerebro que sangra, soy un temblor de tierra [...].

Altazor 4: Después de mi muerte un día, el mundo será pequeño a las gentes, plantarán continentes sobre los mares [...] Habrá ciudades grandes como un país, gigantescas ciudades del porvenir, en donde el hombre-hormiga será una cifra, un número que se mueve y sufre y baila.

Altazor 2: Ángel expatriado de la cordura cpor qué hablas, quién te pide que hables? (Huidobro, Obras completas, 368).

En estos fragmentos se condensan sintéticamente algunas de las figuras asumidas por el personaje que serán escenificadas en el trascurso de la acción: el antipoeta, el animal, el ángel, el mago. El antipoeta autónomo de la realidad, tiene su correspondencia en la figura del superhombre que predica Nietzsche a través de Zarathustra: una persona capaz de generar su propio sistema de valores: «el hombre es algo que debe ser superado» (Nietzsche, 76). Para Huidobro, la poesía será por excelencia la forma de superación del hombre. Así, el antipoeta estaría en un mismo plano referencial con el Anticristo. Desde la figura del superhombre pasa a la del animal, autodesignándose como un perro, encarnando al ser protector y benéfico, así como también al impuro y al maldito. Luego se separa abruptamente de su yo para trasladar su mirada crítica al sistema histórico social en el que está inserto. En un acto desesperado, Altazor reniega de la vida: rechaza la ley natural de la procreación ya que es un acto absurdo y sin sentido, donde se ponen seres humanos en el mundo desprovistos de un significado último y decisivo a la existencia.

Altazor 2: El mundo se me entra por los ojos / Se me entra por las manos se me entra por los pies

Altazor 3: Me entra por la boca y se me sale / En insectos celestes o nubes de palabras por los poros (Huidobro, Obras completas, 384). 
Hacia el final del canto en el devenir ángel, el cuerpo de Altazor se trasforma y se reviste de una capacidad engendradora, donde ocurren la fecundación, la germinación y el alumbramiento. Altazor-mago-ángel alude simbólicamente al acto materno de 〈dar a luz〉 a la poesía. El mundo lo penetra, lo posee, lo fecunda, se rehace y sale, exteriorizándose en otras formas. Este acto es orgánico y mágico, producido por la entrada de los objetos en su cuerpo; se trata de una trasmutación de las cosas, donde todo lo que rodea al personaje se transforma. De esta manera, se realiza el proceso poiético impulsado por la metáfora dando lugar a imágenes novedosas. Como se puede dar cuenta en estos y otros fragmentos citados, la mayor parte de dichas imágenes tienen que ver con la conexión establecida entre los objetos y el cuerpo del personaje.

Las múltiples figuras escenificadas por el personaje proyectan imágenes que se sintetizan en: cuerpo animal, cuerpo máquina, cuerpo geográfico, cuerpo humano, cuerpo celeste, y el poema funciona como un registro de esta (auto)percepción. Todas estas representaciones buscan la universalidad, y se conectan con la idea del «todo hombre». Esta noción, o también hombre total〉 — desarrollada por Huidobro en el manifiesto Total- expresa la necesidad de un individuo conectado con el universo, en permanente comunión entre el corazón y la mente y yendo más allá de una realidad concebida en los binarismos (razón/sentimiento, sueño/realidad). Otra lectura posible en conexión a la línea de análisis propuesto hasta ahora, es la relación entre el concepto del ‘todo hombre〉 y la retórica ya descrita en torno al cuerpo del personaje que crea figuras estables y repetidas a lo largo de todo el poema (terreno, astro, ángel, animal, máquina, etc.), haciendo que el personaje participe de todas las naturalezas posibles (naturaleza celeste, animal y humana; naturaleza de cosa y celestial).

En ambas escenas - la poética y la teatral - se muestra cómo el protagonista se mueve creando sus propias fronteras de circulación (su propio espacio) poniendo en evidencia la relación intrínseca entre él y la acción.

\section{CANTO II: EL EROS}

En el montaje, ésta es una escena dedicada al amor de pareja. Los personajes se transforman en cuerpos sexuados, exteriorizando esta característica en alguna parte del vestuario y los movimientos, convirtiéndose en mujeres y hombres. Estos nuevos personajes se juntan formando parejas, cada una ejecuta una secuencia coreografiada de movimientos, presentando distintas cualidades del amor: la delicadeza, lo sutil, el deseo, la violencia, el rechazo y la posesión. Una voz en off recita algunos versos del canto. En el poema, el estado de enamoramiento tiene como objeto la figura de la mujer; en la puesta en escena no sólo se diviniza la figura femenina sino que se replantea como una oda al amor de pareja (heterosexual y homosexual) y al eros. El espacio interno del personaje está completamente invadido por la provocación que suscita el amor. Para dar paso al canto siguiente en la escena teatral, la transición está marcada por la vuelta al vestuario usado en las escenas anteriores y el cambio de la iluminación y la música. 


\section{CANTO III: EL SPORT DE LOS VOCABLOS}

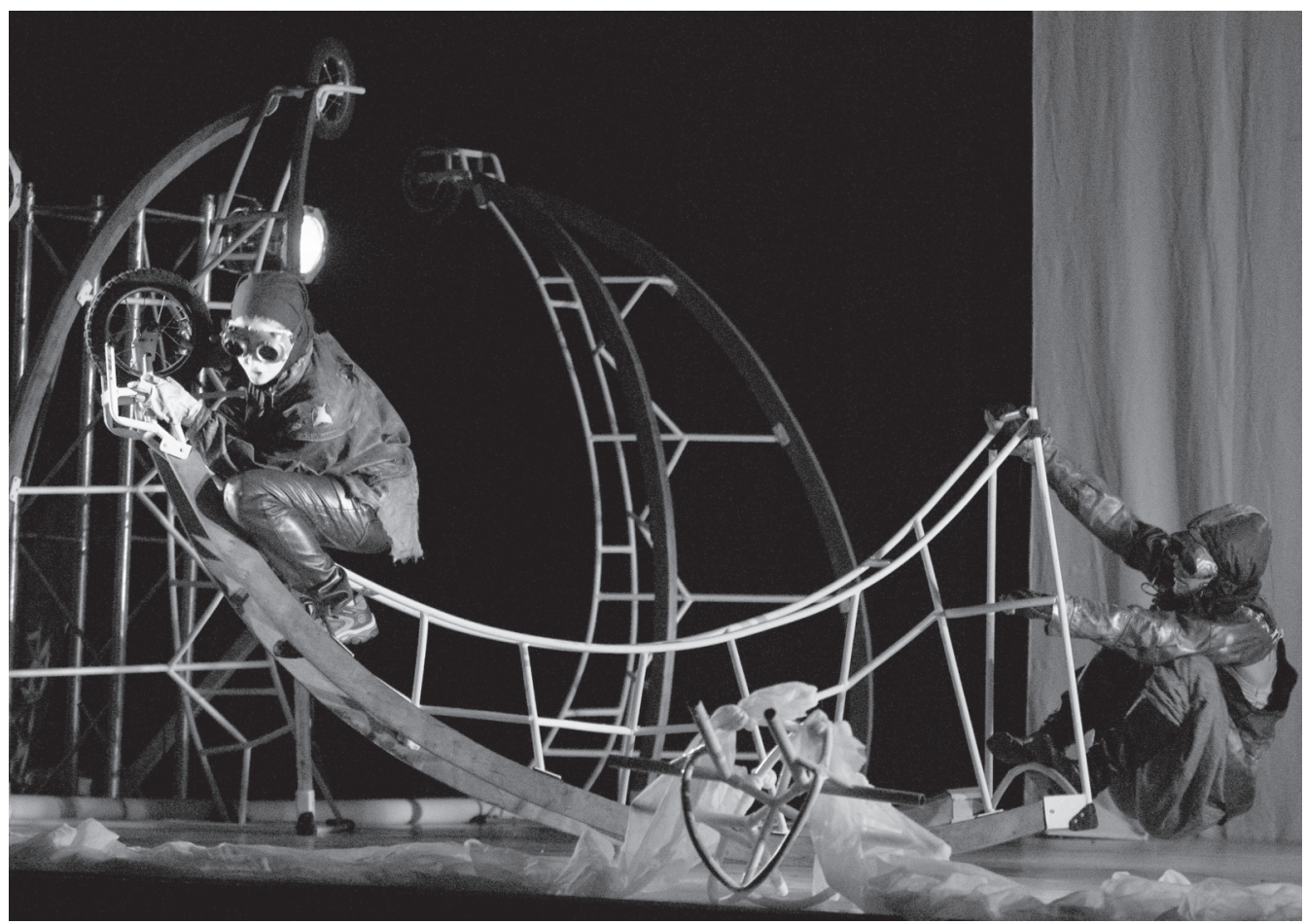

3.- Fotografía de Claudio Quiróz para Un viaje en parasubidas, 2008.

Se retoma el hilo conductor del Canto I y el sujeto en escena retorna al tiempo de la aventura. La idea central de esta estación es insistir en el advenimiento de un nuevo lenguaje, por consiguiente la creación de nuevos mundos. En este canto, se apela a la participación de los sentidos y las pasiones del receptor, y haciendo énfasis en los postulados teóricos de la poética creacionista.

El motivo de la búsqueda y el extravío predominan en la escena y motivan el tránsito del sujeto de una imagen a otra. Los párrafos del texto son breves y separados por espacios en blanco. La trama visual del poema sugiere velocidad y cambio continuo, lo que evidencia la cinesis del personaje. En la escena teatral, cada actor porta una estructura que mueve velozmente por el escenario. El texto es enunciado preferentemente en tono de crítica desde un humor grácil y lúdico, y la dirección pone énfasis en cómo representar con el cuerpo y las estructuras la poética creacionista pensada por Huidobro. Dos son los aspectos que se rescataron: el rechazo de Altazor contra el simulacro de la poesía tradicional y el juego como principal herramienta de combate. El texto enunciado por los actores, las imágenes y acciones presentadas están construidas teniendo en cuenta dichos temas. 
Este canto se centra principalmente en hacer evidente la necesidad de una novedad; en una primera etapa, esta búsqueda se inicia con la burla y la crítica irónica de los órdenes corporales, del sujeto, de la sociedad, y los del lenguaje mismo, para después dar paso a la presentación y desarrollo del motivo del juego. Se trata de un particular procedimiento lingüístico realizado mediante una secuencia de comparaciones de estructura fija. Esta verdadera sgimnasia gramatical, como la llamará el hablante en uno de sus versos, se realiza a través de una sucesión de comparaciones insólitas generadas por la unión de verbos y sustantivos, sin implicancia semántica, y que van describiendo las aventuras poéticas del protagonista. Dichas imágenes surgen de la combinación inusual de elementos conocidos. En la puesta en escena, cada actor recita un verso y el resto del grupo sigue el juego en movimientos al unísono, con o sin estructuras, buscando también en las composiciones coreográficas colectivas la experimentación de tono lúdico y la exaltación del espíritu infantil del personaje.

Altazor 5: sabemos posar un beso como una mirada

Altazor 3: plantar miradas como árboles

Altazor 1: enjaular árboles como pájaros

Altazor 4: vaciar una música como un saco (Huidobro, Obras completas, 392)

El poeta experimenta con las palabras cruzando lo abstracto y lo concreto, lo natural y lo artificial, lo gigante y lo pequeño sobre la base de insólitas analogías. Simbólicamente, el juego alude a la lucha contra la muerte, contra las fuerzas hostiles y también contra uno mismo (el miedo, la debilidad y las dudas); «combate, azar simulacro o vértigo, el juego es por sí mismo un universo, donde conviene con aventura y riesgo, encontrar un lugar [...] como la vida real pero en un marco determinado con antelación, el juego asocia las nociones de totalidad, regla o libertad» (Chevalier y Cheerbrant, 610). Locura, combate y juego serán las condiciones para la liberación y la creación.

Cuando la escena del juego está en su punto más álgido y frenético, un actor interrumpe desde el público: «no hay tiempo que perder», los demás cortan bruscamente sus acciones y el espacio escénico queda a oscuras, sólo un foco que sigue los movimientos del actor. Un breve monólogo desde el lugar del público es enunciado a un tú; la proximidad a nivel de discurso y a nivel corporal hace de esta escena un momento íntimo.

\section{CANTO IV: EL SPORT DE LOS VOCABLOS II}

Tanto en la escena poética como en la puesta en escena, el Canto IV se desarrolla en especial continuidad con el canto precedente, desarrollando la idea del juego pero enfocado en la figura del mago y sus actos venideros. Los experimentos con el lenguaje y la construcción de «imágenes puras` son cada vez más radicales, destacando la construcción de motivos líricos y lingüísticos ${ }^{16}$; estos consisten en la reiteración y la combinación con otras palabras, buscando en ello infinitas combinaciones de amplitud semántica.

16 Los motivos o leitmotiv refieren a elementos repetidos en una obra. En este análisis se utilizarán dos terminologías: los motivos lingüísticos que remiten a palabras o grupos de palabras recurrentes a lo largo de la obra, y el leitmotiv o motivo propiamente tal que designa temas o elementos repetidos sometidos a variaciones. 
A través de este mecanismo, el poeta transgrede el nivel gramatical y semántico de las palabras en función de lo que está expresando. En esta parte, podemos reconocer tres motivos en orden de aparición: el ojo, la golondrina, rosiñol. En la puesta en escena se retoma el leitmotiv 〈golondrina〉 para mostrar el juego lingüístico —en el plano del discurso enunciado - y en el juego corporal - la enunciación ilustrada con movimientos y acciones corporales que muestran la reacción de los personajes de frente a este nuevo objeto maravilloso.

La alusión recurrente a cuerpos volantes como aves o máquinas voladoras (a nivel de texto lingüístico y corporal) remiten continuamente al motivo del vuelo y el viaje. Dichos objetos hablan también de la necesidad del personaje de despojarse de lo superficial, y lo no trascendental, en el camino hacia la liviandad y la libertad. Todos estos aspectos son también las principales líneas de dirección sugeridas a los actores para guiar la interpretación. El ave conecta el cielo y la tierra, sugiere libertad y liviandad del peso de lo terreno, en suma, un estado superior del ser; el vuelo del ave tiene que ver con la trasmisión de un saber y la conexión con lo trascendental que mueve a Altazor. Dicha acción, sugerida en el animal y en los cuerpos celestes, también es evocada en la prótesis del paracaídas que se adhiere al cuerpo del personaje y que permitió su vuelo durante los primeros estadios del viaje.

El poder transformador de Altazor da origen a objetos que se alejan cada vez más de su realidad; las palabras son trasformadas mediante un collage lingüístico: horitaña, firmazonte, golonfina, marería, rodoñol, rosiñol, meteópalos, eterfinifrete, espaverso, etc ${ }^{17}$. La combinación inusual de palabras y partes de palabras, genera poco a poco la separación cada vez más drástica con las referencias en la realidad.

Se ha recalcado que el deseo de aventura es un aspecto persistente en la composición del carácter del personaje y que indudablemente permanece ligado al motivo de la muerte, ya que a medida que el personaje se va desligando de lo conocido, el peligro y la incertidumbre aumentan; esta conciencia es también trágica. La muerte es el destino de lo conocido y también el desafío de Altazor. En relación a este reconocimiento, el segundo motivo desarrollado en este canto tiene que ver con un homenaje en memoria a los caídos. El personaje encuentra las tumbas de otros ‘caídos en la travesía), que como él quisieron emprender el viaje sin llevarlo a su fin. El texto enunciado por cada actor es un pequeño homenaje personal. Adicional al recitado del texto, el actor hace uso de unas pequeñas cajas blancas adosadas a las estructuras, que al abrirse emiten una luz que se proyecta en el rostro de quien la abre.

Despojado Altazor del recuerdo y la fatalidad con la que se había identificado hasta ese momento, el personaje da un paso más hacia lo desconocido, hacia lo nunca visto ni realizado hasta ese momento. La transición al próximo canto está marcada por la trasformación del espacio realizada por los actores. Cada uno toma una estructura y la traslada hacia la «cuarta pared, de manera que el centro del escenario quede vacío. Vuelve la música a la escena.

17 M. García Pinto desarrolla este concepto, describiendo éstas y otras construcciones como ejemplos de la técnica creacionista presente en el poema. 


\section{CANTO V: EL ESPACIO VACÍO}

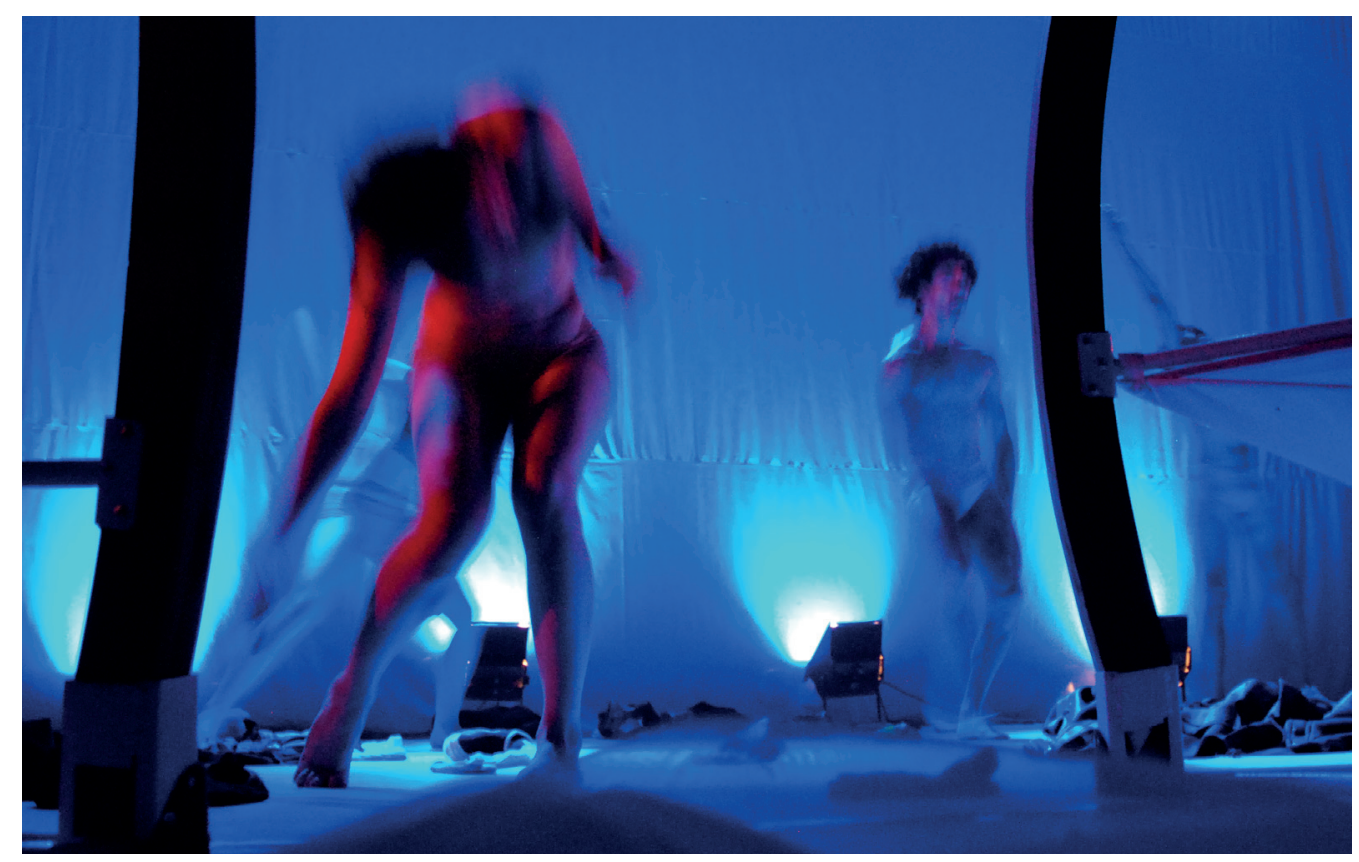

4.- Fotografía de Claudio Quiróz para Un viaje en parasubidas, 2008.

El espacio vacío es la preparación al advenimiento de algo todavía nuevo: aquí comienza el campo inexplorado / Redondo a causa de los ojos que lo miran /Y profundo a causa de mi propio corazón [...] Hay un espacio despoblado / Que es preciso poblar (Huidobro, Obras completas, 402).

Tal como el texto lo anuncia, esta estación involucra el descubrimiento y la transformación. Concretamente, las ideas se exteriorizan en la primera acción que realizan los personajes en este nuevo lugar: el despojo de sus ropas. La ropa es signo de la carga del pasado y los prejuicios; elementos de los que el personaje debe desprenderse para que acontezca algo distinto. Esta entrada a zonas inexploradas no se realiza fuera del sujeto sino en su propio cuerpo y dentro de él. Las indicaciones de dirección al respecto son generales: cada actor a su propio tiempo, desde la intención que escoja según su carácter e identidad, debe presentar lo que el despojo significa para sí mismo — pudiendo ser doloroso, alegre, impaciente, terrorífico, entre otros- No sólo esta acción revela la transformación del personaje, la enunciación del discurso también es una posibilidad de mostrar, lo cual es enunciado explorando principalmente en su soporte fonológico: alargan las vocales, repiten sílabas y juegan con distintas entonaciones y volúmenes de voz.

El despojo es un camino al autoconocimiento. En este camino, el cuerpo es proyectado como espejo de un espacio interno, donde su transformación da origen a un organismo nuevo con una apariencia distinta, se mueve, respira y habla distinto. Una vez 
desnudos, los cuerpos muestran una kinética distinta: circular, central, leve y laxa que se puede apreciar en las secuencias coreografiadas de danza al unísono. Poco a poco las corporalidades de los personajes, en un principio tan diferenciadas, se van homologando. En este sentido, a medida que la acción trascurre en la puesta en escena, la denominación de «cuerpo〉 se puede ampliar a una estructura material y física, perceptible sensorialmente y viva, un organismo. Las imágenes suscitadas en el texto poético apelan a la materialidad, aspecto sugerido en la implicancia inventada por el poeta entre las palabras creadas y las conocidas y el cambio semántico sufrido por las palabras desde la animalización, la cosificación o la personificación de palabras creadas.

Todos: La herida de luna de la pobre loca / La pobre loca de la luna herida /Tenía luz en la celeste boca / Boca celeste que la luz tenía / El mar de flor para esperanza ciega / Ciega esperanza para flor de mar / Cantar para el ruiseñor que al cielo pega / Pega el cielo al ruiseñor para cantar (Huidobro, Obras completas, 405).

Otro procedimiento recurrente en el canto, ya comentado anteriormente, es la exploración de las posibilidades fonológicas y morfológicas que ofrece una palabra al ser sometida al cambio: las jitanjáforas (farandolina, lejantaña, montanía, horimento, firmazonte, musicá). Goic reflexiona sobre este procedimiento, caracterizándolo como un proceso que da lugar a un «texto cuyo sentido reposa en el significante y está construido desde valores puramente sonoros (ritmos, aliteraciones, etc.). En ella pueden eventualmente reconocerse palabras conocidas, en otros casos sólo el sonido cuenta» (La poesía de Vicente Huidobro, 180).

La descripción de estados internos ha quedado relegada a segundo plano, importan el aspecto gráfico y fónico del lenguaje en virtud del desarrollo de la historia. En relación a lo anterior, el discurso está dominado por una focalización externa, sin mayores alusiones a sentimientos o estados internos del sujeto.

Una estación clave dentro de la escena del Canto $V$ es la peculiar disposición de más de cien versos donde el objeto de caracterización es el molino. Las frases están conformadas mediante anáforas, con la repetición del sustantivo ‘molino`, más una preposición o conjunción y un sustantivo o verbo en gerundio, lo que genera en cada final de verso una rima consonante. Esta disposición especial del texto sugiere la idea de la obsesión y las sensaciones de vértigo y exasperación, y al mismo tiempo se detiene el tiempo de la narración al focalizar la descripción en un solo objeto. A partir de ese caligrama, el movimiento circular del molino es evocado en la configuración visual del espiral. Con esta estrategia, se tratan de emular las cualidades cinéticas del movimiento, lo que también está presentado en la ductilidad de las palabras y su transformación.

En la puesta en escena, los movimientos y coreografías adquieren marcadas cualidades circulares, tanto en el movimiento de los actores como de los trayectos en el espacio; en esta estación se exterioriza la energía creadora como una fuerza centrífuga y circular. Movimiento periférico, amplio y continuo son las cualidades kinéticas predominantes de los cuerpos. La energía del movimiento circular es expansiva y centrífuga, de acuerdo a esta característica, los actores van expulsando fuera de él las piezas de ropa y todos los elementos que se quitaron. Una vez liberados, la intensidad de la música y los movimientos ceden gradualmente para buscar el silencio en el espacio nuevamente vacío. La disminución en la intensidad del movimiento atrae los cuerpos hacia las estructuras, cada uno se fusiona y acoge a ella, la escena queda en silencio corporal y auditivo. 


\section{CANTO VI: LA REVELACIÓN}

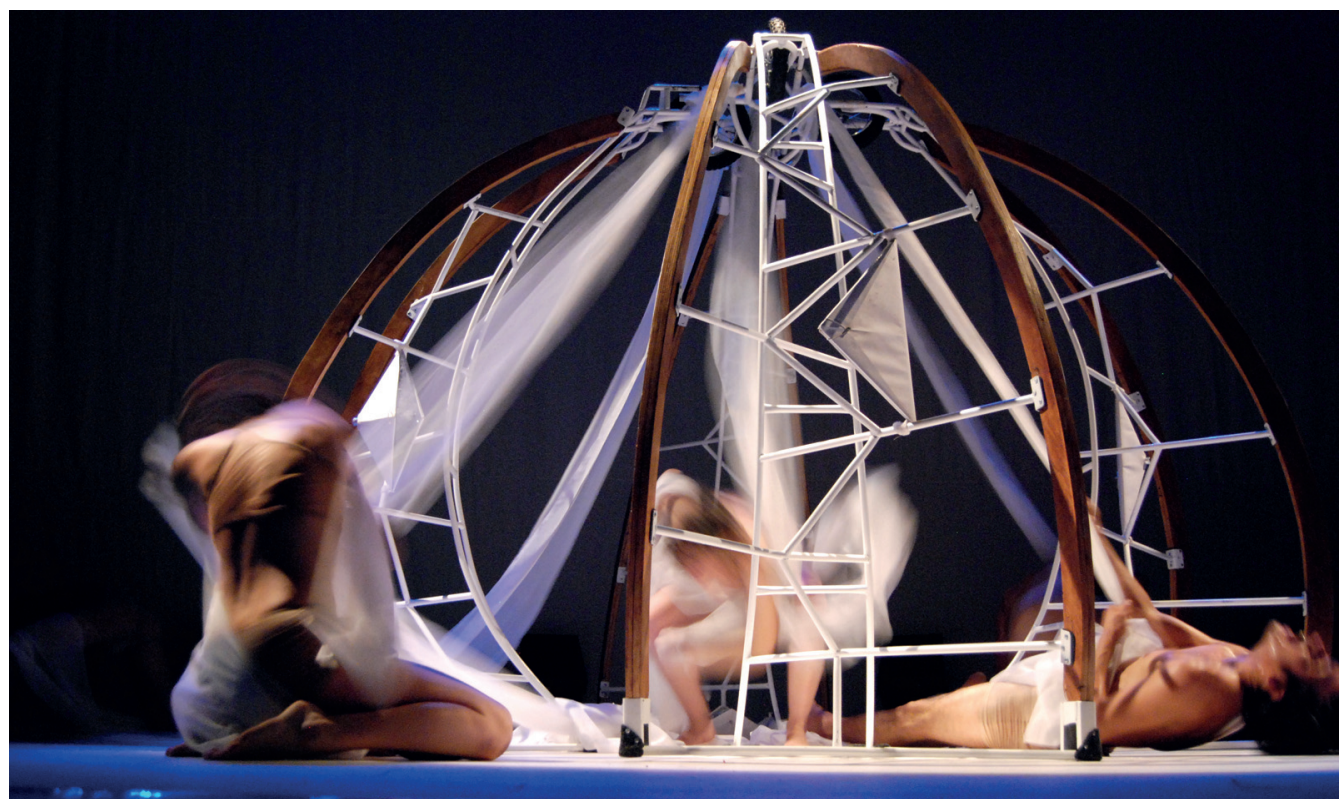

5.- Fotografía de Claudio Quiróz para Un viaje en parasubidas, 2008.

La escena del Canto VI expone otro nivel aún más radical en este viaje. Radical por la ruptura manifiesta al lenguaje hasta ahora desarrollado en el poema, las leyes morfológicas, sintácticas y semánticas de las palabras quedan en segundo plano. La subjetividad del protagonista se diluye entre las palabras sueltas y agrupadas arbitrariamente sin coherencia sintáctica para, hacia el final del canto, aparecer cortadas en sus sílabas y agrupadas con otros segmentos de palabras. Esta reformulación constante refleja la ruptura con el aspecto denotativo del lenguaje.

El espacio, el cuerpo del actor y los elementos en escena son resignificados en esta estación. Los actores en escena llenan el espacio vacío con las estructuras que disponen en el centro del escenario, formando con ella una cúpula circular. Uno de los actores toma un objeto que permanecía en el centro del escenario y lo lleva sobre la figura armada con las estructuras. De dicho objeto cuelgan unas telas blancas que son movidas por los actores hacia el centro del semicírculo. Luego cada uno enlazado a una tela, salen arrastrándose hacia los extremos del escenario. Emiten sonidos y ruidos diversos. Todos estos signos en escena revelan la evidente transformación del personaje pero sin representar una figura en concreto: se evocan movimientos de animales o estados físicos (sensaciones corporales) y los textos recitados son casi incomprensibles. El texto del poema en este canto está construido por varias estrofas con versos de extensión variable, formando una elipsis o una figura que ondula hasta el final del párrafo. Esta trama visual, ya conformada en otros cantos, sugiere las ideas de ondulación, flexibilidad, continuidad y amplitud. El espiral como símbolo remite al movimiento circular desde un centro, desde un punto original que se 
prolonga indefinidamente. Chevalier y Cheerbrant señalan en relación a esta figura: «sus movimientos trasmiten dos sentidos: la vida y la muerte o la muerte iniciática y el renacimiento de un ser trasformado» (479). Los contenidos simbólicos del viaje están en directa relación con algunos sugeridos por la figura del espiral: como el poema lo demuestra, el viaje del personaje es un camino hacia sí mismo, el despojo de lo superficial en la vuelta al origen. El viaje de Altazor tiene como objetivo ese centro unificador donde nace todo.

El texto del canto ya no remite a estados de ánimo; lo pictórico pasa a primer plano para crear imágenes a partir de las referencias entregadas por una o más palabras que, como en la imitación de un montaje cinematográfico, son presentadas una tras otra como en un collage. El juego metafórico de implicancia o sustitución de funciones que ha predominado a lo largo del poema es reemplazado por la pura referencialidad de las palabras que se logran distinguir en el texto; se trata de un mecanismo desintegrador cada vez más radical que no resta musicalidad y ritmo al lenguaje del poema.

Todos: (a diferentes tiempos y repitiendo si es necesario) Cristal si cristal era / Cristaleza / Magnetismo / sabéis la seda/ Viento flor / lento nube lento / Seda cristal lento seda /El magnetismo /Seda aliento cristal seda (Huidobro, Obras completas, 418).

Siguiendo la línea del desarrollo global del relato de Altazor, la escena del Canto VI pone de manifiesto la búsqueda hacia un posible origen que yace en los estadios más íntimos del ser y las cosas.

\section{CANTO VII: ESTADO DE LATENCIA}

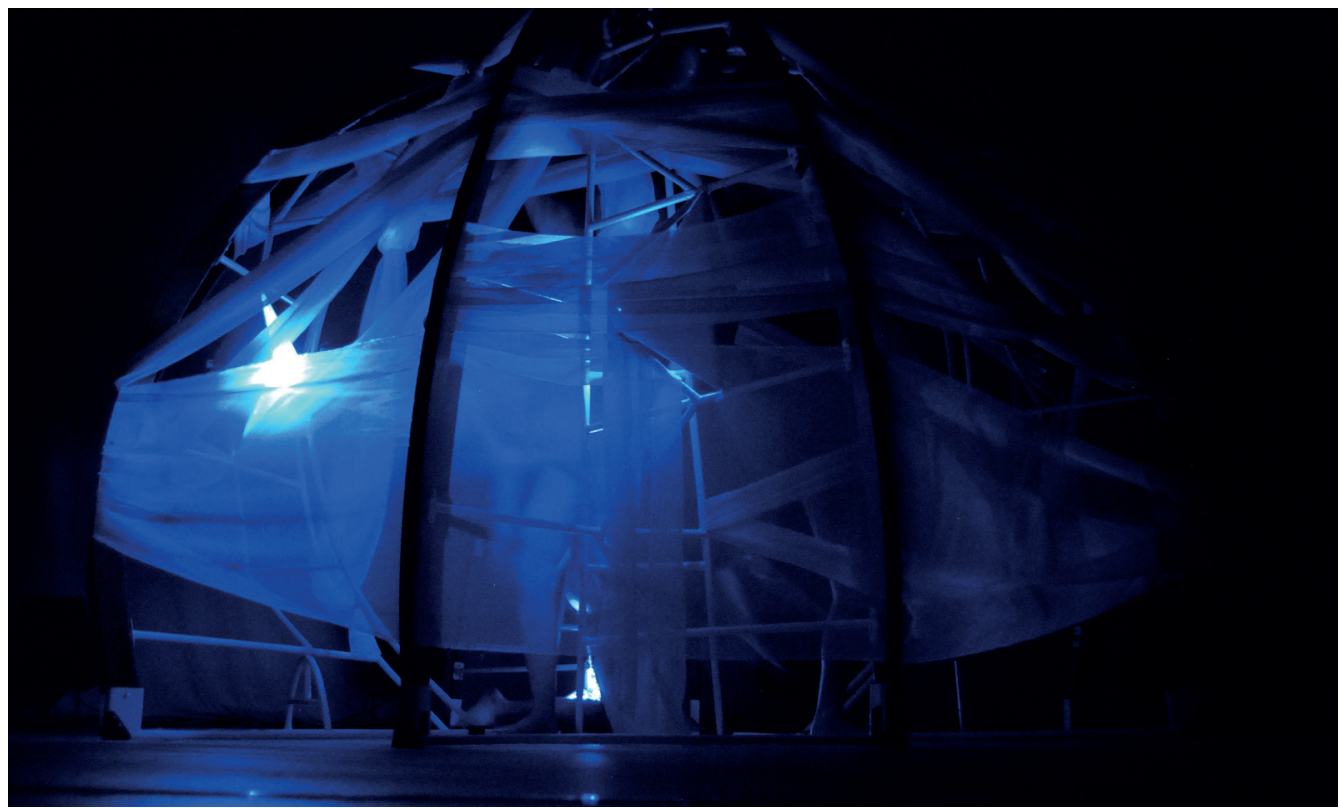

6.- Fotografía de Claudio Quiróz para Un viaje en parasubidas, 2008. 
El viaje del personaje y el fin del relato parecen llegar al fin en este canto. El sujeto representado en el lenguaje no está referido en conceptos ni imágenes, sino a través de sonidos. El sustrato expresivo de la lengua se rearticula en favor de la pura sonoridad, privilegiando lo fónico. El espacio construido a través del discurso alude a una atmósfera particular y capaz de significar por sí misma: es autocreado. El valor referencial del lenguaje se pierde completamente, por tanto, el significado atribuido al canto es formulado en relación a los principales signos y su interpretación señalados hasta este punto.

En la puesta en escena, los actores se movilizan hacia el interior del semicírculo luego de cubrirlo con las telas. La relación que el actor revela con la figura creada presenta la idea de la estancia en el útero materno, el feto y su cordón umbilical; dentro de ella el movimiento de los actores es leve, liviano, circular y central; los cuerpos parecen moverse en el agua, alternando también entre la quietud y las descargas de energía súbitas. A través de los intersticios del entramado de la figura, se pueden ver los cuerpos de los actores, muy juntos y componiendo en sí. Se mantiene la homogeneidad del estado corporal, los movimientos y las sensaciones que transmiten, buscando la unidad orgánica. Las líneas de dirección se mantienen constantes desde la estación anterior: el cuerpo debe volverse delicado y dúctil como el agua, la liviandad y la gravedad cero son las cualidades predominantes en el movimiento.

El espacio que contiene los cuerpos simboliza el germen, el punto original de la vida, la fertilidad y la continua capacidad de renacer. La particularidad de este renacimiento es que se realiza desde un mundo que el mismo personaje construye por propia voluntad. El texto es presentado en el conglomerado de las voces de los actores que hablan a un tiempo y en murmullo. La palabra alterada morfosintáctica y fonéticamente da origen a un discurso construido en base a una gran cantidad de elipsis, onomatopeyas y sílabas sueltas, sin que dicha fragmentación pierda musicalidad: «ai aiiiiii aia, ululayu, luluayo, lari taram» (Huidobro, Obras completas, 422). Este particular tratamiento lingüístico evoca los primeros estadios de desarrollo del lenguaje de los niños. Algunos investigadores interpretan esta arquitectura escalonada del canto y del poema en general como un ascenso ceremonial al cielo, y como Ícaro en camino al aniquilamiento ${ }^{18}$.

Durante esta estación, se elimina paulatinamente la música, el texto y la iluminación, el volumen de la voz desciende a medida que los movimientos se van haciendo más lentos y sutiles, de manera de focalizar la mirada del receptor en el cuerpo y las sensaciones que evoca. El espacio del sujeto en escena está plena y únicamente ligado al mundo de las percepciones en la evocación de los sonidos. La presentación sonora de esta nueva realidad es exclusivamente sensorial, una percepción sonora de la emoción.

El lenguaje desintegrado del texto enunciado por los actores, refleja el estado de transformación del personaje a una fase germinativa. De acuerdo a todos estos antecedentes, la búsqueda del sujeto hacia el interior y la conquista de la propia plenitud, adquieren la forma simbólica de un renacimiento, en la vuelta al útero materno. Se han anulado las oposiciones y los binarismos en el discurso, el hablante se instala desde otro lugar de representación. Para el lector se trata de un lenguaje no codificado pero absolutamente provisto de significado ya que se inserta dentro de la trama de sentido que propone la acción.

18 Sobre este punto véase las lecturas desarrolladas por: Goic 2003, Yurkievich 1979, Hahn 1999, Schopf 2003, Sucre 1985, Hey 1979. 
Este estado de latencia es el que terminará con la acción de Un viaje en parasubidas. Recalco que se trata de un estado de latencia, ya que una de las más significativas acotaciones del director, se sustenta en este punto: el final que se propone en la obra no está marcado por una muerte propiamente tal; la muerte es un despojo simbólico que se repite muchas veces a lo largo de la historia, Altazor es un personaje en constante evolucióninvolución. La obra pone en evidencia la capacidad de búsqueda del sujeto, el poder de sus deseos y su voluntad.

El viaje arquetípico finaliza con esta llegada. Arribo que se representa en la disección y fragmentación del lenguaje. El sujeto ha logrado traspasar la capa que recubre lo visible para llegar a destino; un ciclo se completa y da paso a otro nuevo, donde el lenguaje poético se encarga de presentar el cuerpo de un nuevo ser en un nuevo mundo.

\section{CONCLUSIONES}

En ambos relatos - en la escena teatral y en la poética一, se presenta el relato del viaje arquetípico de Altazor movido por la búsqueda imperiosa del origen y el sentido último de las cosas, travesía que lo lleva irremediablemente a sí mismo. La aventura de Altazor implica el tránsito hacia estadios cada vez más internos de su personalidad; por consiguiente, el viaje simboliza también la negación de un individuo que rompe las ataduras de una realidad y la transforma. Ambos textos, insertos en una trama histórica y social, construyen una alegoría del mundo moderno y de sus individuos.

El estudio del sujeto en la escena permitió precisar diferentes trayectos y transformaciones del personaje. Esta conexión entre sujeto y acción, nos lleva a reconocer que las escenas descritas están configuradas en relación al estado interno del personaje, es decir, la escena poética y la escena teatral presentan dos modos de exteriorización de una situación interna de quien realiza la acción, tendiendo a la presentación visual de lo descrito. La evidenciación de los estados internos del personaje/hablante lírico se realiza en el texto, a nivel de entramado lingüístico y metalingüístico, y en el montaje a través del cuerpo del actor, el discurso enunciado y el resto de los dispositivos escénicos. En este estudio, el énfasis fue puesto en la exteriorización a través del cuerpo siendo posible trazar una retórica del mismo (o también las distintas formas de nombrarlo) común en ambos objetos artísticos. Ésta permitió diseñar un inventario de figuras, imágenes condensadas de significado que remiten a una localización orgánica de estados internos del sujeto sugeridos en la acción.

Este proceso de exteriorización a través del cuerpo fue posible mediante la interacción metafórica de los elementos que circulan en el poema, apuntando a la primacía de lo sensorial, especialmente de lo visual, por sobre la expresión de una idea. Es de esta manera que el cuerpo se constituye en el lugar principal de enunciación/mostración y significación de un discurso, siendo también materia simbólica inserta en una trama de sentidos sugeridos en ambos objetos artísticos. El texto poético y la puesta en escena son actos performativos en el contexto de una producción discursiva, donde el discurso se realiza, y la acción se sucede, preferentemente en el cuerpo del sujeto en escena.

Si bien el código poético y el código teatral comprenden sistemas de signos diversos, es posible comparar el traslado y las similitudes entre ambos focalizando en la corporalidad 
de los sujetos y el análisis de la escena. Por lo anterior, no se puede dejar de reconocer el valioso aporte del estudio del cuerpo y los materiales de la escena en el campo de la literatura y el teatro.

Valoro el poema Altazor o el viaje en paracaídas de Vicente Huidobro como un texto dramático, al que subyace el desarrollo de una acción y la presencia de un sujeto que la realiza. Dicho texto preexiste a la puesta en escena, y se constituye en su soporte dramático. En relación a lo anterior, Un viaje en parasubidas exalta lo visual en el poema, el cuerpo y el gesto del actor, lo espacial y lo cinético, para presentar con ello una de las tantas lecturas elaboradas en tono al poema. Dicha enunciación escénica, es el resultado de un sistema de relaciones de producción (actores, director), una propuesta crítica que actualiza el texto poético.

La perspectiva expuesta en este estudio es un intento por exponer la correspondencia entre los estudios literarios y teatrales; instala la investigación en un contexto cultural de producción, lo que hace posible la entrada de conceptos de otras disciplinas en el campo de los estudios literarios, poniendo en evidencia el cruce entre el lugar del crítico y del intérprete, exponiendo su complementariedad y retroalimentación.

\section{REFERENCIAS}

Aristóteles. Poética. trad. de Valentín García Yebra. Madrid: Editorial Gredos, 1974. Medio impreso.

Bobes Naves, Carmen. La metáfora. España: Editorial Gredos, 2004. Medio impreso.

Chevalier, Jean y Alain Cheebrant, Diccionario de símbolos. Barcelona: Herder, 1995. Medio impreso.

Contreras, Marta. «Escenas casi familiares en Fantasmas borrachos, de Radrigán, en la puesta en escena de Francisco Albornoz. O un estudio del amor y la soledad con un poco de humor». Acta literaria 29 (2004), 149-154. Medio impreso.

Contreras, Marta. «Introducción». Griselda Gambaro: teatro de la descomposición. Concepción: Universidad de Concepción, 1994. Medio impreso.

Goic, Cedomil. «La comparación creacionista: Canto III de Altazor». Revista Iberoamericana 106-107 (1979). 129-139. Medio impreso.

Goic, Cedomil. La poesía de Vicente Huidobro. Santiago. Ed. Anales de la Universidad de Chile, 1928. Medio impreso.

Goic, Cedomil y otros. Vicente Huidobro: Obra poética. Santiago. Ed. Universidad Católica de Chile, 2003. Medio impreso.

Ferrater Mora, José. Diccionario de filosofía, tomo II. Buenos Aires: Ed. Sudamericana, 1965. Medio impreso.

García Pinto, Magdalena. «El bilingüismo como factor creativo en Altazor». Revista Iberoamericana 106-107 (1979). 115-127. Medio impreso.

González, Luis y Dieter Oetker. Diccionario de los movimientos y grupos literarios chilenos. Concepción: Ediciones Universidad de Concepción, 1993. Medio impreso.

Hahn, Oscar. Vicente Huidobro o el atentado celeste. Santiago: Lom Ediciones, 1999. Medio impreso. 
Hey, Nicolás.«Nonsense en Altazor». Revista Iberoamericana 106-107 (1979). 149-156. Medio impreso.

Huidobro, Vicente. Obras completas, tomo II. Santiago: Ed. Zig-Zag, 1964. Medio impreso.

- Obras selectas: Poesía. Santiago: Ed. del Pacífico, 1997. Medio impreso.

Laban, Rudolph. El dominio del movimiento. Madrid: Editorial Fundamentos, 1987. Medio impreso.

Marchese, Angelo y Joaquín Forradelas. Diccionario de retórica, crítica y terminología literaria. Madrid: Editorial Ariel, 2000. Medio impreso.

Nietzsche, Friedrich. Así habló Zarathustra. Madrid: Ed. Sarpe, 1983. Medio impreso.

Paz, Octavio. Los hijos del Limo. Barcelona: Seix Barral, 1998. Medio impreso.

Pavis, Patrice. Diccionario de Teatro. Paidós: Buenos Aires, 2008. Medio impreso

Rodríguez, Marta. "Mito y articulación poiética de la metáfora en los sistemas poiéticos de Vicente Huidobro y José Lezama Lima». Delirio y metáfora: Vicente Huidobro y André Breton. Santiago: Ed. Delirio poético, 2000. Medio impreso.

Savater, Fernando. La tarea del héroe. Barcelona: Ed. Destino, 1992. Medio impreso.

Schopf, Federico. Vicente Huidobro: Obra poética. Santiago: Ed. Universidad Católica de Chile, 2003. Medio impreso.

Sucre, Guillermo. «Huidobro: altura y caída». La máscara de la transparencia. México: Fondo de Cultura Económica, 1985. Medio impreso.

Toro, Fernando de. Semiótica del teatro, del texto a la puesta en escena. Buenos Aires: Editorial Galena, 1987.

Yurkievich, Saúl. "Altazor. La metáfora deseante». Revista Iberoamericana 106-107 (141- 164). 1979. Medio impreso. 